Yulia A. Vaserchuk

Professor, Candidate of Art History

Institute of Contemporary Art, Department of Graphic Design

e-mail: vasse@yandex.ru

Moscow, Russia

ORCID 0000-0002-0111-8874

DOI: 10.36340/2071-6818-2021-17-2-138-150

\title{
PROJECT CULTURE OF TEAM STRATEGIES
}

Summary: Modern forms of design activities that contribute to the development of professional design are considered in the article. The principles of designers' teamwork, which are similar in structure but differ in content, are compared. In one case, this is teamwork; in the other, groups of like-minded people. It has been proved that colleagues unite by common values, meanings, and ideological attitudes to form a picture of the future and formulate a global vision of professional strategies, design principles, methods, and attitudes to improve the quality of life. By joint intellectual and spiritual efforts, like-minded people form the vector of modern design activity. The professional elite acts as the driving force behind the evolutionary transformation of contemporary design, reveals the potential of conscious design and advanced design thinking, determines the place of design in the future professions, and sets moral standards of behaviour.

The types of project design thinking (from engineering, creative - to artistic and resource one) are presented as

In modern practice, design is often represented by an individual form of project activity, as evidenced by a significant increase in remote work and freelancing. The demand for freelancers in large organisations doubled from 2017 to 2020 [Bentley, 2019]. A freelancer can contribute to a company without being part of it [Singh, 2019]. Such individuals can transform companies' fortunes, allowing them to expand significantly to meet increased demand or complement teamwork with experiences that companies could never have obtained or justified otherwise [Bentley, 2019].

When defining freelancing principles, it is essential to understand that such work involves remote but, nevertheless, quite close interaction with colleagues. One can design remotely from anywhere, but the distance does not mean separation from commu- the results of the individual creativity of team members. The continuous development of certain areas of design thinking and the acquisition of competencies based on individual capabilities provides designers with long-term professional development, regardless of external conditions. Moreover, an honest attitude towards oneself and one's abilities promotes a deep understanding of the profession, which allows the development of new types of design that respond to deep human needs.

In conclusion, self-knowledge, gained in a collective creative act, promotes the development of individual abilities and leads to intellectual and spiritual co-evolution.

Keywords: Project design culture, team, a group of like-minded people, teamwork, freelance, collective design, competencies, types of thinking, strategy, conceptual design, project design thinking, co-evolution, Russian design.

nications. To earn money, a freelancer needs partners. Thus, freelancing is not as isolated an activity as it might seem [Ghosh, 2017]. However, a designer, especially when working remotely, is rarely seen as a team player within a design team. He or she is not involved in creating team strategies; the intellectual potential of a freelancer is seldom used in fundamental development. In the modern world, the ability of a designer to visualise an already formed image, to realise someone else's vision is appreciated. Marketing strategists lead the design process and choose directions based on consumer preferences, sometimes actively developing them.

The development of freelancing, the positioning of design as an individual creative activity, as well as the myth that design is a profession for introverts, in a sense, hinder the development of collective forms 
of design, prevent designers from being aware of themselves as part of a team, and prevent professionals from becoming active participants in collective intellectual co-creation. Only a fraction of designers realise that team design surpasses the capabilities of an individual due to its multidimensional scope, which enriches the final results of activities. The resource of teamwork in design has not been fully identified and not fully updated. In reality, even as a result of the proliferation of freelancing and other "non-team" work formats, design has every opportunity to implement group practices, integrate interdisciplinary project sessions, and develop design tools in line with creative team technologies.

In the spring of 2020, the covid-19 pandemic and the associated self-isolation fully demonstrated that remote communication does not interfere with productive teamwork in many professional areas, including design. In a difficult period for everyone, project sessions, seminars organised on the platforms Skype, Webinar, Webex, Zoom, and others allowed specialists to unite to solve urgent design and business problems, strengthen human ties, and develop interpersonal communication.

In the modern world, with an increase in the level of stress, the factor of psychological support in the form of a voluntary union of people comes to the fore. This natural reaction of society stops disunity, compensates for the lack of quality communication, contributes to the emergence and strengthening of like-mindedness. At the same time, consent is viewed not only as an intellectual but also as a psychicemotional, spiritual unity. Human capital, for which the team serves as support since the value of the individual contribution to the common cause of all participants is multiplied many times over, is of particular importance. A team is an organism that unites people by a common cause and a common spirit.

Currently, the concept of teamwork, which means the ability of a group of people to work well together, is widespread [Cambridge Advanced Learner's Dictionary, 2019]. Also, the meaning includes working to achieve common goals and tasks most acceptably and effectively by a group of interconnected people, a team... The word "work" in the concept of teamwork is the key, meaning-forming basis of the phrase. Effective teamwork considers the knowledge, skills, abilities and other characteristics of its members [Bell, 2015: 181]. Group cohesion is one of the most researched constructs affecting team efficiency and productivity [Severt, 2015: 3], contributing sig- nificantly to team success. Research into cohesion mechanisms can diagnose, monitor, and improve team performance [Grossman, 2015: 147]. Special attention is paid to two criteria of team cohesion the organisational commitment of team members and their social competence [Hirunyawipada, 2015: 855], as well as efficiency factors based on well-being: subjective well-being (SWB) and psychological well-being (PWB) [Vanhove, 2015: 53]. Interpersonal relationships of team members, such as friendship, do not have a positive relationship with the consistency of tasks and the desirable qualifications of the ideas generated by the group [Hirunyawipada, 2015: 855]. However, there is a positive relationship between team effectiveness and the emotional state of the group. Associations that develop group emotional consciousness and can manage emotional connections within the group become more productive and learnable [Ghuman, 2016: 51]. For the teamwork model, professional, business relationships formed to solve corporate problems optimally are decisive; and emotional closeness, empathy, seems to be a kind of "safety cushion" in interpersonal relationships.

In Russian practice, in addition to the teamwork model appropriate for business relations, a form of uniting people on the principle of like-mindedness has been formed, which in fact goes beyond the simple unity of participants with a similar mentality and way of thinking; it implies cohesion at a deeper spiritual level. Emotional unity and creative atmosphere are presented not only as tools that form cohesion but also as the business intentions of professional groups, the existential meaning of their creativity. In most cases, people meet, unite for mutual support and mutual assistance. Often, a common cause is just a pretext for team interaction. The luminary of the Russian design culture, V. Glazychev, noted that "at the seminar, people come together; there is a mutual exchange between them, and it is not so important whether any project will arise here and now or not. If it appears, it is great; if it does not, it is okay: it will appear next time. Most importantly, a different experience has been achieved. The participants looked at other people, heard different opinions, saw different approaches, which is very important... Experience is transmitted only in this way - from person to person" [Glazychev]. The presence of goodwill in professional creative associations and unions seems to be significant. People are ready for meetings and project sessions, having internal motivation, interest 
in the innovative development of design, in the enrichment of the industry, its individual development in the process of gaining collective experience. Joint "living" of the creative process in a team of people close in spirit greatly enriches all its participants, fills their lives with energy.

"A team of like-minded people" - seems to be the most accurate definition for this kind of group. At the same time, like-minded people are people united by a common intellectual and cultural level, a similar vector of spiritual development, sharing similar values and ideological attitudes. This cultural feature has always been a certain obstacle to the rapid and successful implementation of Western business models, forms of organisation and management of project activities, business communications and teamwork standards into Russian project processes. In our country, joint design is most often based on the principles of openness, reflectivity, and most importantly, the creation of innovative projects, methodological developments, and other "products" of collective thought activity that enrich practice [Marfin, 2005: 15]. It has always been important for representatives of the professional environment (higher education, design practice) to agree on common "vanishing points" and then build a methodological framework for design, relying on a mature conceptual base with various individual theoretical developments and practical experience.

Modern Russian designers still remember and honour the traditions of artistic design, the theoretical and methodological experience of the AllRussian Research Institute of Technical Aesthetics (VNIITE), the Institute's project seminars, conferences, publications, famous throughout the Soviet Union, focused on the development of creative reflection, the development of a professional-critical approach to the results of their own activities, the vision of its objects in a broad socio-cultural context [Jerdev, 2007: 8]. The results of collective project activities are included in numerous reports on the scientific and methodological work of the Institute, in methodological recommendations based on the results of project seminars, in materials of international and Russian scientific conferences, in pre-project and project documentation: explanatory notes to artistic design proposals, in reports on the results of the examination of Russian and foreign design products.

Teamwork is somewhat different from the traditional forms of project co-creation for the post-
Soviet space. First of all, the difference is in goal setting, which creates corporate strategies and progressive business solutions. For Russian models of co-creation, goal-setting, as a rule, is guided by the principle "to make the world a better place". Also, a distinctive feature is a method of recruiting specialists into teams. For a team of like-minded people, friendship and human acceptance are significant motives for unity. The teamwork model presupposes the integration of team members according to the "constructor" principle, combining the knowledge, skills and abilities required for project development. For successful work, groups of people are formed with competencies in several disciplines and additional skills that allow professionals to work, listen and learn from each other while jointly solving problems [Redström, 2017: 11]. The combinatorial principle of team modelling, based on the competencies and project experience of the participants, helps to unite people for the implementation of projects of different directions. Short distances, successfully covered by the team together, presuppose the further development and transformation of teams into new associations to cover the next distances. The interchangeability and flexibility of teams formed on a competency basis enable people to get acquainted, exchange experience and knowledge, broaden their horizons and learn how to interact with representatives of different fields of activity effectively. Depending on the composition of the created team, the group members each time look for a new method of practical problem solving, carry out personal growth, and develop the leader's personal qualities. Leaders of successful collaborations demonstrate increased emotional and social competence, take actions to improve and progress in the future, remain mission-oriented and ready for a change to meet current challenges [Madden, 2015: 18].

The consistency of the value range of its participants with the general preferences of corporationscustomers is an essential factor affecting the efficiency of teamwork project work. "The perception of different types of values and their manifestation would be useful for managers in understanding how to identify the causes of the gap between the personal values of employees and the values of the organisation and take targeted actions to ensure the consistency of values within companies" [Vveinhardt, 2017: 2003]. In Western forms of teamwork, management of value models serves, as a rule, the strategic goals of companies and the paradigm of 
the market economy in general. Today, team design, subject to the observance of agreed values, has become a driver of successful design developments in the field of brand development, individual products, services and business areas for foreign and many Russian companies. Teamwork for design is an effective tool for finding solutions, including user-centric research to prototype future successful designs, as well as collective creativity to strengthen individuals, teams and organisations [Madden, 2015: 18]. Strategic design, based on teamwork, has established itself as an effective weapon in the competitive struggle; it brought design methods to the level of creating social prerequisites for the emergence of in-demand goods and services. It became capable of influencing society, ecology, demography and other spheres of life through products and services, patterns of consumer behaviour and communication.

In Russian design, strategy is seen as something more complex, going beyond the solution of specific business problems of individual corporations. The tactical level of social design is also perceived to be insufficient in the absence of global design philosophy. For collectives of like-minded people, the primary factor in uniting people is the consistency of the value series, the commonality of deep ideological attitudes, a common understanding of the goals and meanings of joint intellectual and project activities. This approach contributes to the joint passage of long-term distances. It also has a high potential for developing complex strategic design and forming a project philosophy. The consistency of the fundamental foundations and meanings of design as a future design technology allows a team of like-minded people to carry out a design based on a common value paradigm for a long-term perspective.

Western corporate culture, business communications, teamwork formats sometimes look lightweight for people who grew up in the Soviet and post-Soviet eras. Corporate culture often becomes an object of ridicule in Russia since it does not reach the level of true culture as a complex of philanthropy, nobility and intelligence in a sense familiar to compatriots. A team of like-minded people, united by spiritual values and a common desire to change the world for the better, is needed to carry out complex strategic project activities. Such globality of design installations is formed by the revolutionary spirit of changing historical paradigms. The Russian design practice is characterised by a broad scope and global vision, including the procedure for developing fundamental concepts of the world order. At the same time, the discussion of global problems is associated with the human dimension of the world order, with the development of concepts, international institutions and procedures, the object of which is human potential and various types of humanitarian activities [Genisaretsky, 1996]. It is evidenced by the statements of the leading Russian specialists in the field of conceptual design: G. Shchedrovitsky, V. Glazychev, O. Genisaretsky.

Consistency in the vision of the outlines of the future is a condition for uniting people into teams of like-minded people. Strategic design, systemic interaction of people to create a predictive concept carries a rich, creative, cultural, intellectual and spiritual potential. The team as a creative unit is no longer formed through the competencies and design skills inherent in the teamwork model but owing to the intellectual, spiritual unity, empathy of members of a team of like-minded people. The ability for spiritualised communication and like-mindedness forming on its basis is put at the forefront. "The designer was faced with traditionally 'non-design' tasks: the humanisation of relations, all-round development of personality, etc... This means the inclusion of the most diverse! specialists in a common (not by duty but by spirit) cause" [Shurov, 2011: 49].

The formation of a team of like-minded people is closely related to the organisation of the thinking process in the group. "A seminar is an action for the sake of trying to start creating other thoughts, or rather, thinking activities" [Glazychev]. In design practice, involving interdisciplinary project sessions and seminars, as well as other forms of combining professionals, competencies that confirm what a specialist knows and can do give way to principles that determine how he or she thinks. In project thinking, several types of intellectual orientation can be distinguished, which are determined by natural talent. These include various types of thinking: creative (from heuristic - to combinatorial), technical (from design - to engineering), organisational (from communicative and informational - to managerial), figurative (from metaphorical - to connotational), creative or artistic (from colour-graphic - to volumetric-spatial), futuristic (from scientific to strategic), resource (from spatial to content), organisational (from structural to managerial), and so on. At the same time, knowledge and skills, competencies 
and project experience are only a consequence of the cognitive abilities of the group members. "Design thinking is a sequence of cognitive and other operations that is considered a universal way to solve a problem" [Ro, 2016: 249]. The types of thinking with apparent closeness can appeal to entirely different cognitive abilities of a person, his or her mental dispositions and natural talents.

With a detailed segmentation of particular types of design thinking, it is essential to understand the range and capabilities of design thinking, consisting of intelligent individuals - specialists of different giftedness. "Design engineering is a meeting place and integration of the multiple experiences of the collective mind" [Freire, 2017: 92]. The exchange of energies, emotions, knowledge and approaches to design is the value and wealth of design activities. The design processes themselves take the team of like-minded people to an entirely new level of self-awareness. Here, deep-seated attitudes are manifested, which are characteristic not only of individuals but also of the collective consciousness as an integral intellectual and spiritual organism. Owing to team actions, thoughts and images are repeatedly refracted and reflected, multiplied, freed from unnecessary things, finding their only true form and meaning for a given space and time. It can be safely asserted that intellectual collective self-knowledge and self-awareness are carried out through project-based creative activity, which leads to co-evolution - joint development and all-around enrichment.
Today, co-evolution as a joint, interdependent existence and development is rarely understood as a collective resource. Competitive methods are constantly prevalent in the profession. Knowledge, skills and abilities work not for the joint result of the community but for the natural desire to stand out within the team. However, the investment of time and labour in the accumulation of competencies is meaningful only when one or another knowledge, skills and abilities are integrated into the team project field. The basic principle of win-win is the primary condition for co-evolution, high-quality joint development in a team. With an internal attitude towards team interaction, the global professional community is interpreted as an extension of the individual creative self beyond the capabilities of the individual - to a worldwide scale.

Strategic design, carried out by a team of like-minded people, as a future-oriented project concept has development prospects in our country. Russian design, which had been in the sociallyoriented, humanistic paradigm of design creativity for almost the entire 20th century, is adaptive to the social tasks of the global design of a high-quality future. Preserving and increasing human values, creating futuristic images, determining the desired place of a person in the future, developing principles of behaviour in society and organising communication between people are the real aims of work for Russian designers who want to create a harmonious world for themselves and future generations.

\section{REFERENCES}

1. Genisaretsky, O.I. On the Human Dimension of the Future World Order Congress [Electronic resource] Access mode: www.olegen.com/synergistic-anthropology/ a2/culture-russia/dimension/- congress-humandimension-b/. (access date: 05.08.2020).

2. Glazychev, V.L. Methodology for Conducting Project Seminars [Electronic resource] Access mode: http://www.glazychev.ru/projects/seminars/seminar_ metodology.htm. - (access date: 05.08.2020).

3. Jerdev, E. V. 2007. "The Role of VNIITE in the Development of Russian Industrial Design", Design Review. Information Scientific and Practical Journal. Kazan: Design-kvartal, no. 1-4, pp. 8-12.

4. Marfin, S. G. 2005. "Problem Seminars - a Way of Forming a Team of Like-minded People", Professional education. Moscow: Academia professionalnogo obrazovania, no. 4, pp. 15-16.
5. Ro, O. 2016. "Is the Evolution of Higher Education Keeping up with the Revolution of Opportunities?", Collection of materials of the International Scientific and Practical Conference Russian Creative Education in the Field of Digital Art in Accordance with EU Standards, Moscow: Stroganov MGHPA, pp. 243-256.

6. Shurov, V. A. 2011. "From 'Design Thinking' to 'Design Being'", Design Review. Information scientific and practical journal. Kazan: Design-kvartal, no. 1-2, p. 49.

7. Bell, S. T. 2015. "Selecting and Composing Cohesive Teams", Research on Managing Groups and Teams, vol. 17. Team Cohesion: Advances in Psychological Theory, Methods and Practice, pp. 181-209.

8. Bentley, D. Freelance Rates and Market Guide 2019. Australian Creative Services \& Digital Industry [Electronic resource] / Access mode: https://www.cavalryfreelancing.com/wp-content/uploads/Cavalry_Rates_ Guide_2019.pdf. (access date: 05.08.2020). 
9. Cambridge Advanced Learner's Dictionary \& Thesaurus [Electronic resource]. Access mode: https://dictionary. cambridge.org/dictionary/english/teamwork. (access date: 05.08.2020).

10. Freire, K. 2017. "From Strategic Planning to the Designing of Strategies: A Change in Favor of Strategic Design", Strategic Design Research Journal, 10 (2) São Leopoldo, RS, Brasil: Publicação da Universidade do Vale do Rio dos Sinos Unisinos, pp. 91-96.

11. Ghosh, S. 2017. Career \& Opportunities in Freelancing Kindle Edition. New Delhi, Delhi: Diamond Pocket Books, p. 110.

12. Ghuman, U. 2016. "An Empirical Examination of Group Emotional Intelligence in Public Sector Workgroups", Team Performance Management, vol. 22 (1-2), pp. 5174.

13. Grossman, R. 2015. "What Matters for Team Cohesion Measurement? A Synthesis", Research on Managing Groups and Teams, vol. 17. Team Cohesion: Advances in Psychological Theory, Methods and Practice, pp. 147-180.

14. Hirunyawipada, T. 2015. "Toward the Development of New Product Ideas: Asymmetric Effects of Team Cohesion on New Product Ideation", Journal of Business \& Industrial Marketing, vol. 30, no. 7, pp. 855-866.

15. Madden, J. R. 2015. The Collaboration Blueprint: Designing and Building Effective Strategies for Innovation and
Rejuvenative Collaboration. Cleveland, $\mathrm{OH}, \mathrm{USA}$ : Triple alumna of Case Western Reserve University, p. 223.

16. Redström, J. 2017. Making Design Theory. Cambridge, MA: The Massachusetts Institute of Technology Press, p. 170.

17. Severt, J. B. 2015. "On the Function and Structure of Group Cohesion", Research on Managing Groups and Teams, vol. 17. Team Cohesion: Advances in Psychological Theory, Methods and Practice, pp. 3-24.

18. Singh, A. Freelance Data Scientist [Electronic resource]. Access mode: https://www.researchgate.net/publication/332539068_Freelance_Data_Scientist. (access date: 05.08.2020).

19. Vanhove, A. J. 2015. "Team Cohesion and Individual Well-Being: A Conceptual Analysis and Relational Framework", Research on Managing Groups and Teams, vol. 17. Team Cohesion: Advances in Psychological Theory, Methods and Practice, pp. 53-82.

20. Vveinhardt, J. 2017. "Congruence of Personal and Organizational Values: Structuring Components of the Phenomenon", Proceedings of the $29^{\text {th }}$ International Business Information Management Association Conference Education Excellence and Innovation Management Through Vision 2020 from Regional Development Sustainability to Global Economic Growth, pp. 1003-1017. 
Юлия Анатольевна Васерчук

профессор кандидат искусствоведения

Институт современного искусства, кафедра графического дизайна

e-mail: vasse@yandex.ru

Москва, Россия

ORCID 0000-0002-0111-8874

DOI: 10.36340/2071-6818-2021-17-2-138-150

\section{ПРОЕКТНАЯ КУЛЬТУРА КОМАНДНЫХ СТРАТЕГИЙ}

Аннотация: В статье рассматриваются современные формы дизайнерской деятельности, способствующие развитию профессионального проектирования. Сопоставляются близкие по форме, но отличающиеся по содержанию принципы коллективной работы проектировщиков. В одном случае - это рабочие команды teamworks, в другом - группы единомышленников. Выявлено, что соратники объединяются под флагом общих ценностей, смыслов, мировоззренческих установок для формирования картины будущего и постановки глобального видения стратегий профессиональной деятельности, проектных принципов, методик и установок, нацеленных на повышение качества жизни. Совместными интеллектуальными и духовными усилиями единомышленники формируют вектор современной дизайнерской деятельности. Профессиональная элита выступает движущей силой эволюционного преобразования современного дизайна, выявляет потенциал осознанного дизайн-проектирования, развитого дизайн-мышления, определяет место дизайна в профессиях будущего, задаёт нравственные эталоны поведения.

Типы проектного дизайн-мышления (от инженерного, креативного - до художественного и ресурсного)

Дизайн в современной практике зачастую представлен индивидуальной формой проектной деятельности, о чём свидетельствует значительный рост объёмов удалённой работы и фриланса. Спрос на фрилансеров в крупных организациях с 2017 по 2020 год удвоился [Bentley, 2019]. Фрилансер может внести свой вклад в компанию, не будучи её частью [Singh, 2019]. Такие люди способны изменить состояние компаний, позволяя им значительно расширяться для удовлетворения возросшего спроса или дополнять командную работу опытом, который в противном случае компании никогда не смогли бы получить или оправдать [Bentley, 2019]. представлены в виде результатов индивидуального творчества участников команды. Непрерывное развитие тех или иных областей проектного дизайн-мышления и обретение компетенций, исходя из индивидуальных возможностей, обеспечивает проектировщикам долгосрочное профессиональное развитие вне зависимости от внешних условий. Более того, честное отношение к себе и своим способностям содействует глубокому пониманию профессии, что позволяет развиваться новым видам дизайна, отвечающим на глубинные человеческие запросы.

В завершении делается вывод, что самопознание, обретаемое в коллективном творческом акте, содействует раскрытию индивидуальных способностей и ведёт к интеллектуальной и духовной коэволюции.

Ключевые слова: Проектная культура дизайна, команда, коллектив единомышленников, teamwork, фриланс, коллективное дизайн-проектирование, компетенции, типы мышления, стратегия, концептуальный дизайн, проектное дизайн-мышление, коэволюция, отечественный дизайн.

Определяя принципы фриланса, важно понимать, что такая работа предполагает удалённое, но, тем не менее, достаточно плотное взаимодействие с коллегами. Удалённо можно проектировать, находясь в любом месте, но дистанцированность не означает отрыв от коммуникаций. Чтобы зарабатывать, фрилансеру необходимы партнёры. Таким образом, фриланс - не настолько изолированный тип деятельности, как это может показаться [Ghosh, 2017]. Тем не менее, дизайнер, особенно если он работает удалённо, редко рассматривается как командный игрок в коллективе проектировщиков. Его не привлекают для создания командных стратегий, интеллектуальный 
потенциал фрилансера редко используют в принципиальных разработках. В современном мире ценятся способности дизайнера визуализировать уже сформированный образ, реализовывать чужое видение. Стратеги от маркетинга возглавили процесс проектирования и осуществляют выбор направлений исходя из потребительских предпочтений, а порой и активно их формируя.

Развитие фриланса, позиционирование дизайна как индивидуальной творческой деятельности, а также миф о том, что дизайн - профессия для интровертов, в известном смысле мешают развитию коллективных форм проектирования, не позволяют дизайнерам осознавать себя частью команды, мешают профессионалам стать активными участниками коллективного интеллектуального сотворчества. Только часть дизайнеров осознаёт, что командное проектирование превосходит возможности индивидуального благодаря своему многоаспектному охвату, обогащающему конечные результаты деятельности. Ресурс командной работы в дизайне до конца не выявлен и не актуализирован в полной мере. В реальности, даже вследствие распространения фриланса и прочих "некомандных» форматов работы, дизайн имеет все возможности для реализации практик групповой деятельности, внедрения междисциплинарных проектных сессий, развития инструментов проектирования в русле креативных командных технологий.

Пандемия covid-19 и связанная с ней самоизоляция в полной мере продемонстрировали весной 2020 года, что удалённые способы взаимодействия не мешают продуктивной коллективной работе во многих профессиональных сферах, в том числе и в сфере дизайна. Проектные сессии, семинары, организуемые на платформах Skype, Webinar, Webex, Zoom и пр., в непростой для всех период позволили специалистам сплотиться для решения актуальных задач дизайна и бизнеса и укрепить человеческие связи, развить межличностное общение.

В современном мире при возрастании уровня стресса на первый план выходит фактор психологической поддержки в виде добровольного союза людей. Эта естественная реакция общества купирует разобщённость, компенсирует дефицит качественного общения, содействует возникновению и укреплению единомыслия. При этом согласие рассматривается не только как интеллектуальное, но и как психически-эмоциональное, духовное единение. Особое значение имеет человеческий капитал, которому команда служит поддержкой и опорой, так как многократно умножается ценность индивидуального вклада в общее дело всех участников. Команда является организмом, объединяющем людей не только общим делом, но и общим духом.

В настоящее время распространено понятие «Teamwork», что означает способность группы людей хорошо работать вместе [Cambridge Advanced Learner's Dictionary, 2019], а также оно включает в себя работу по достижению общих целей и выполнению задач наиболее адекватным и действенным способом группой взаимосвязанных людей, командой. Слово «работа» (work) в понятии teamwork является ключевой, смыслообразующей основой фразы. При эффективной командной работе учитываются знания, навыки, способности и другие характеристики её членов [Bell, 2015: 181]. Сплочённость группы является одним из наиболее исследуемых конструктов, влияющих на эффективность команды, её производительность [Severt, 2015: 3], и вносит значительный вклад в командный успех. Исследования механизмов сплочённости позволяют диагностировать, контролировать и улучшать показатели команды [Grossman, 2015: 147]. Особое внимание уделяется двум критериям командной сплоченности - организационной приверженности членов команды и их социальной компетентности [Hirunyawipada, 2015: 855], а также факторам эффективности, основанным на благополучии: субъективном благополучии (subjective well-being SWB) и психологическом благополучии (psychological well-being PWB) [Vanhove, 2015: 53]. Межличностные отношения членов команды, такие как, например, дружба, не имеют положительной связи с согласованностью задач и желательной квалификацией созданных группой идей [Hirunyawipada, 2015: 855]. Однако положительная связь наблюдается между командной эффективностью и эмоциональным настроем группы. Объединения, которые развивают групповое эмоциональное сознание и могут управлять эмоциональными отношениями внутри группы, становятся более продуктивными и способными к обучению [Ghuman, 2016: 51]. Для модели командной работы teamwork профессиональные, деловые отношения, сформированные в целях оптимального решения корпоративных задач, являются определяющими, а эмоциональная близость - эмпатия - представляется своего 
рода «подушкой безопасности» в межличностных связях.

В отечественной практике помимо уместной для деловых отношений модели teamwork сформировалась форма объединения людей по принципу единомыслия, которая по факту выходит за рамки простого единения участников со схожей ментальностью и образом мыслей, а подразумевает сплочённость на более глубоком духовном уровне. Эмоциональное единение и творческая атмосфера представляются не только инструментами, формирующими сплочённость, но и деловыми интенциями профессиональных групп, экзистенциальным смыслом их творчества. В большинстве случаев люди встречаются, объединяются ради взаимоподдержки и взаимопомощи. Зачастую общее дело является лишь предлогом для командного взаимодействия. Корифей отечественной проектной культуры В.Л. Глазычев отмечал, что «на семинаре люди сходятся вместе, и между ними происходит взаимный обмен, и не так уже важно, возникнет ли здесь и сейчас какой-либо проект или нет. Возникнет - прекрасно, если нет, то ничего страшного: значит, возникнет в следующий раз. Важно, что появился другой опыт. Участники посмотрели на других людей, услышали другие мнения, увидели другие подходы, и это очень важно... Опыт передаётся только так - от человека к человеку» [Глазычев]. Значимым представляется наличие доброй воли в профессиональных творческих объединениях и союзах. Люди готовы на встречи и проектные сессии, имея внутреннюю мотивацию, заинтересованность в инновационном развитии дизайна, в обогащении отрасли, её индивидуальном развитии в процессе обретения совместного опыта. Совместное «проживание» творческого процесса в коллективе близких по духу людей в значительной мере обогащает всех его участников, наполняет их жизнь энергией.

«Коллектив единомышленников» - представляется наиболее точным определением для подобного рода команды. При этом единомышленники - люди, объединённые общим интеллектуальным и культурным уровнем, схожим вектором духовного развития, разделяющие схожие ценности и мировоззренческие установки. Данная культурная особенность всегда была некоторой преградой для быстрого и успешного внедрения в отечественные проектные процессы западных бизнес-моделей, форм организации и управления проектной деятельностью, деловых коммуникаций и стандартов teamwork. Совместное проектирование в нашей стране чаще всего строится на принципах открытости, рефлективности, а самое главное - создания инновационных проектов, методических разработок, других «продуктов» коллективной мыследеятельности, обогащающих практику [Марфин, 2005: 15]. Представителям профессиональной среды (высшей школы, дизайнерской практики) всегда было важно договориться об общих «точках схода» и далее выстраивать методологический каркас дизайна, опираясь на зрелую понятийную базу при всём многообразии индивидуальных теоретических разработок и практического опыта.

Современные отечественные проектировщики ещё помнят и чтут традиции художественного конструирования, теоретический и методологический опыт Всероссийского научно-исследовательского института технической эстетики (ВНИИТЭ), знаменитые на весь Советский Союз проектные семинары Института, конференции, издания, ориентированные «на развитие творческой рефлексии, выработку профессионально-критического подхода к результатам собственной деятельности, видение её объектов в широком социально-культурном контексте» [Жердев, 2007: 8]. Результаты коллективной проектной деятельности содержатся в многочисленных отчётах о научнометодической работе Института, в методических рекомендациях по итогам проектных семинаров, в материалах международных и отечественных научных конференций, в предпроектной и проектной документации: пояснительных записках к художественно-конструкторским предложениям, в докладах о результатах экспертизы отечественной и зарубежной дизайнерской продукции.

Коллективная работа teamwork несколько отличается от традиционных для постсоветского пространства форм проектного сотворчества. В первую очередь этот водораздел проходит через область целеполагания, создающую корпоративные стратегии и прогрессивные бизнес-решения. Для отечественных моделей сотворчества целеполагание, как правило, руководствуется принципом - «сделать мир лучше». Также отличительной чертой является метод подбора специалистов в команды. Для коллектива единомышленников дружба и человеческое приятие являются значимыми мотивами единения. Модель teamwork предполагает интеграцию членов команды по принципу «конструктора», 
стыкующего знания, умения и навыки, необходимые для разработки проекта. Для успешной работы формируются группы людей с компетенциями в нескольких дисциплинах и дополнительными навыками, позволяющими профессионалам работать, слушать и учиться друг у друга при совместном решении задач [Redström, 2017: 11]. Комбинаторный принцип моделирования команд, основанный на компетенциях и проектном опыте участников, способствует объединению людей для реализации проектов разной направленности. Короткие дистанции, успешно пройденные командой совместно, предполагают дальнейшее развитие и трансформацию команд в новые объединения с целью прохождения следующих дистанций. Взаимозаменяемость и гибкость команд, сформированных на компетентностной основе, дают возможность людям знакомиться, обмениваться опытом и знаниями, расширять кругозор и учиться эффективно взаимодействовать с представителями разных областей деятельности. В зависимости от состава созданной команды участники групп каждый раз ищут новый метод результативного решения задач, осуществляют личностный рост, развивают персональные качества руководителя. Лидеры успешного сотрудничества демонстрируют повышенную эмоциональную и социальную компетентность, предпринимают действия, направленные на улучшения и прогресс в будущем, остаются ориентированными на миссию и готовы к изменениям для решения текущих задач [Madden, 2015: 18].

Важным фактором, влияющим на эффективность проектной работы teamwork, является согласованность ценностного ряда её участников с общими преференциями корпораций-заказчиков. «Восприятие различных типов ценностей и их проявление было бы полезно руководителям в понимании того, как выявлять причины разрыва между личными ценностями сотрудников и ценностями организации и предпринимать целенаправленные действия для обеспечения соответствия ценностей внутри компаний» [Vveinhardt, 2017: 2003]. Управление ценностными моделями в западных формах коллективной работы служит, как правило, стратегическим целям компаний и парадигме рыночной экономики в целом. Командное проектирование при условии соблюдения согласованных ценностей стало сегодня для зарубежных и многих отечественных компаний драйвером успешных проектных разработок в области развития брен- дов, отдельных продуктов, услуг и направлений бизнеса. Командная работа teamwork для дизайна - это эффективный инструмент поиска решений, включающих исследования, ориентированные на конечного пользователя, в целях создания прототипов будущих успешных дизайнрешений, а также коллективное творчество для укрепления отдельных лиц, команд и организаций [Madden, 2015: 18]. Стратегический дизайн, опирающийся на командную работу teamwork, зарекомендовал себя как эффективное оружие в конкурентной борьбе, он вывел методы проектирования на уровень создания социальных предпосылок для появления востребованных товаров и услуг. Он стал способен через продукты и услуги, модели потребительского поведения и коммуникации воздействовать на общество, экологию, демографию и прочие сферы жизни.

Для отечественной проектной мысли cmpameгия видится как нечто более комплексное и выходящее за рамки решения конкретных бизнес-задач отдельно взятых корпораций. Тактический уровень социального проектирования также воспринимается недостаточным при отсутствии глобальной проектной философии. Для коллективов единомышленников базовым фактором объединения людей является согласованность ценностного ряда, общность глубинных мировоззренческих установок, единое понимание целей и смыслов совместной интеллектуальной и проектной деятельности. Такой подход способствует совместному прохождению долгосрочных дистанций, также у него есть высокий потенциал для развития комплексного стратегического проектирования и формирования проектной философии. Согласованность фундаментальных основ и смыслов дизайна как проектной технологии будущего позволяет коллективу единомышленников осуществлять проектирование, исходя из общей ценностной парадигмы на сколь угодно долгую перспективу.

Западная корпоративная культура, деловые коммуникации, форматы teamwork подчас выглядят легковесными для людей, выросших в советскую и постсоветскую эпоху. Корпоративная культура часто становится в России объектом насмешек, поскольку не достигает уровня истинной культуры как комплекса филантропии, благородства и интеллигентности в привычном для соотечественников смысле. Для осуществления комплексной стратегической проектной деятельности необходима 
команда единомышленников, объединённых духовными ценностями и общим желанием изменить мир к лучшему. Подобная глобальность проектных установок сформирована революционным духом сменяющихся исторических парадигм. Для отечественной проектной практики свойственен широкий охват и глобальное видение, включающие процедуру формирования принципиальных концепций мироустройства. При этом обсуждение глобальных проблем связано с человеческим измерением мирового порядка, с выработкой концепций, международных институтов и процедур, объектом которых является - человеческий потенциал и различные виды гуманитарной деятельности [Генисаретский, 1996]. Об этом свидетельствуют высказывания ведущих отечественных специалистов в области концептуального проектирования: Г.П. Щедровицкого, В.Л. Глазычева, О.И. Генисаретского.

Согласованность в видении очертаний будущего является условием объединения людей в команды единомышленников. Стратегическое проектирование, системное взаимодействие людей с целью создания прогностической концепции - несёт в себе богатый творческий, культурный, интеллектуальный и духовный потенциал. Команда как творческая единица формируется уже не через компетенции и проектные навыки, свойственные модели teamwork, но благодаря интеллектуальному, духовному единству, эмпатии членов коллектива единомышленников. Способность к одухотворённому общению и созревающему на этой базе единомыслию ставится во главу угла. «Перед дизайнером встали традиционно «недизайнерские» задачи: гуманизация отношений, всестороннее развитие личности и т.д. ...Это означает включение самых разнообразных! специалистов в общее (не по долгу, а по духу) дело» [Шуров, 2011: 49].

Формирование команды единомышленников тесно связано с организацией процесса мышления в группе. «Семинар есть действие ради попытки начать создавать другие мысли, а вернее, мыследеятельности» [Глазычев]. В дизайнерской практике, предполагающей междисциплинарные проектные сессии и семинары, а также иные формы объединения профессионалов, компетенции, подтверждающие, что специалист знает и умеет, уступают место принципам, определяющим то, как он мыслит. В проектном мышлении можно выделить целый ряд типов интеллектуальной направленности, которые определяются природным дарованием. К ним относятся различные типы мышления: креативное (от эвристического до комбинаторного), техническое (от конструкторского - до инженерного), организационное (от коммуникативно-информационного - до управленческого), образное (от метафорического - до коннотационного), творческое или художественное (от цвето-графического - до объёмно-пространственного), футуристическое (от научного - до стратегического), ресурсное (от пространственного - до контентного), организационное (от структурного - до управленческого) и т.д. При этом знания и умения, компетенции и проектный опыт являются лишь следствием когнитивных способностей участников группы. «Дизайн-мышление - это последовательность когнитивных и других операций, которая считается универсальным способом решать задачу» [Ро, 2016: 249]. Типы мышления при кажущейся близости могут апеллировать к совершенно разным когнитивным способностям человека, его ментальным предрасположенностям и природным талантам.

При детальной сегментации частных видов дизайн-мышления представляется важным общее понимание диапазона и возможностей проектного мышления, состоящего из интеллектуальных индивидов - специалистов разной одарённости. «Дизайн-проектирование - это место встречи и интеграции многочисленного опыта коллективного разума» [Freire, 2017: 92]. Обмен энергиями, эмоциями, знаниями и подходами к проектированию является ценностью и богатством проектной деятельности. Сами процессы проектирования выводят команду единомышленников на совершенно новый уровень самосознания. Здесь проявляются глубинные установки, свойственные не только индивидуумам, но и коллективному сознанию как целостному интеллектуальному и духовному организму. Благодаря командным действиям мысли и образы многократно преломляются и отражаются, умножаются, избавляются от лишнего, находя свои единственно верные для данного пространства и времени форму и смысл. Можно смело утверждать, что интеллектуальное коллективное самопознание и самоосознание осуществляются посредством проектной творческой деятельности, что ведёт к коэволюции - совместному развитию и всестороннему обогащению.

Коэволюция - совместное, взаимообусловленное существование и развитие - сегодня редко 
понимается как коллективный ресурс. Методы конкурентной борьбы постоянно превалируют в профессии. Знания, умения и навыки работают не на совместный результат сообщества, а на естественное желание выделиться внутри коллектива. Однако инвестиции времени и труда в накопление компетенций являются осмысленными только при интеграции тех или иных знаний, умений и навыков в командное проектное поле. Базовый принцип win-win (выиграть-выиграть) является основным условием коэволюции, качественного совместного развития в команде. При внутренней установке на командное взаимодействие глобальное профессиональное сообщество интерпретируется уже как расширение индивидуального творческого Я за пределы возможностей индивида - до глобальных масштабов.
Стратегический дизайн, осуществляемый командой единомышленников, как ориентированная на будущее проектная концепция имеет перспективы развития в нашей стране. Отечественный дизайн, почти весь XX век пребывавший в социально-ориентированной, гуманистической парадигме проектного творчества, адаптивен к социальным задачам глобального конструирования качественного будущего. Сохранение и преумножение человеческих ценностей, создание футуристических образов, определение желаемого места человека в будущем, разработка принципов поведения в обществе и организация коммуникации между людьми - вот реальный фронт работы для российских дизайнеров, желающих создать гармоничный мир для себя и будущих поколений.

\section{БИБЛИОГРАФИЯ}

1. Генисаретский О.И. О конгрессе «Человеческое измерение будущего миропорядка» [Электронный ресурс] / О.И. Генисаретский.- Режим доступа: www.olegen.com/синергийная-антропология/ а2/культура-россии/измерение/о-конгрессечеловеческое-измерение-б/.- (Дата обращения: 05.08.2020).

2. Глазычев В.Л. Методология проведения проектных семинаров [Электронный ресурс] / В. Л. Глазычев.Режим доступа: http://www.glazychev.ru/projects/seminars/seminar_metodology.htm. - (Дата обращения: 05.08.2020).

3. Жердев Е.В. Роль ВНИИТЭ в развитии российского промышленного дизайна / Е.В. Жердев // Дизайн Ревю. Информационный научно-практический журнал. - Казань: Дизайн-квартал, 2007.№ 1-4.- С. 8-12.

4. Марфин С.Г. Проблемные семинары - способ формирования коллектива единомышленников / С. Г. Марфин // Профессиональное образование.М.: Академия профессионального образования, 2005. - № 4.- С. 15-16.

5. Ро О. Успевает ли эволюция высшей школы за революцией возможностей? / Ольга Ро, Елена Фотьянова // Сборник материалов Международной научно-практической конференции «Российское креативное образование в области цифрового искусства в соответствии со стандартами ЕС» / Под ред. А.Н. Лаврентьева.- М.: МГХПА им. С. Г. Строганова, 2016. - С. 243-256.

6. Шуров В.А. От «дизайн-мышления» к «дизайнбытию» / В.А. Шуров // Дизайн Ревю. Информационный научно-практический журнал.Казань: Дизайн-квартал, 2011. - № 1-2.- С. 49.
7. Bell S.T. Selecting and Composing Cohesive Teams / Suzanne T. Bell, Brown G. Shanique // Research on Managing Groups and Teams. - 2015. - Volume 17. Team Cohesion: Advances in Psychological Theory, Methods and Practice. - P. 181-209.

8. Bentley D. Freelance rates and market guide 2019. Australian creative services \& digital industry [Электронный ресурс] / Dave Bentley. - Режим доступа: https://www.cavalryfreelancing.com/wp-content/uploads/Cavalry_Rates_Guide_2019.pdf. - (Дата обращения: 05.08.2020).

9. Cambridge Advanced Learner's Dictionary \& Thesaurus [Электронный ресурс]. - Режим доступа: https://dictionary.cambridge.org/dictionary/english/teamwork. (Дата обращения: 05.08.2020).

10. Freire $K$. From strategic planning to the designing of strategies: A change in favor of strategic design / Karine de Mello Freire // Strategic Design Research Journal, 10 (2) São Leopoldo, RS, Brasil: Publicação da Universidade do Vale do Rio dos Sinos — Unisinos, 2017.— P. 91-96.

11. Ghosh S. Career \& Opportunities in Freelancing Kindle Edition / Soumen Ghosh. - New Delhi, Delhi: Diamond Pocket Books, 2017. - 110 p.

12. Ghuman $U$. An empirical examination of group emotional intelligence in public sector workgroups / Umar Ghuman // Team Performance Management. 2016. - Volume 22 (1-2). - P. 51-74.

13. Grossman R. What Matters for Team Cohesion Measurement? A Synthesis / Rebecca Grossman, Zachary Rosch, David Mazer, Eduardo Salas // Research on Managing Groups and Teams. - 2015. - Volume 17. Team Cohesion: Advances in Psychological Theory, Methods and Practice. - P. 147-180. 
14. Hirunyawipada $T$. Toward the development of new product ideas: asymmetric effects of team cohesion on new product ideation / Tanawat Hirunyawipada, Audhesh K. Paswan, Charles Blankson // Journal of Business \& Industrial Marketing. - 2015. - Vol. 30 No. 7.- P. 855-866.

15. Madden J.R. The Collaboration Blueprint: Designing and Building Effective Strategies for Innovation and Rejuvenative Collaboration / Jennifer R. Madden.Cleveland, $\mathrm{OH}$, USA: Triple alumna of Case Western Reserve University, 2015. - 223 p.

16. Redström J. Making design theory / Johan Redström. Cambridge, MA: The Massachusetts Institute of Technology Press, 2017. - 170 p.

17. Severt J. B. On the Function and Structure of Group Cohesion / Jamie B. Severt, Armando X. Estrada // Research on Managing Groups and Teams. - 2015. Volume 17. Team Cohesion: Advances in Psychological Theory, Methods and Practice. - P. 3-24.
18. Singh A. Freelance Data Scientist [Электронный ресурc] / Ajit Singh. - Режим доступа: https://www. researchgate.net/publication/332539068_Freelance_ Data_Scientist. - (Дата обращения: 05.08.2020).

19. Vanhove A.J. Team Cohesion and Individual WellBeing: A Conceptual Analysis and Relational Framework / Adam J. Vanhove, Mitchel N. Herian // Research on Managing Groups and Teams. - 2015. - Volume 17. Team Cohesion: Advances in Psychological Theory, Methods and Practice. - P. 53-82.

20. Vveinhardt J. Congruence of personal and organizational values: Structuring components of the phenomenon / Jolita Vveinhardt, Rizwan Raheem Ahmed, Evelina Gulbovaite // Proceedings of the $29^{\text {th }}$ International Business Information Management Association Conference Education Excellence and Innovation Management Through Vision 2020 from Regional Development Sustainability to Global Economic Growth. - 2017. P. 1003-1017. 